\title{
Unravelling the makings for entrepreneurial success: A case study of the Maponya business in South Africa
}

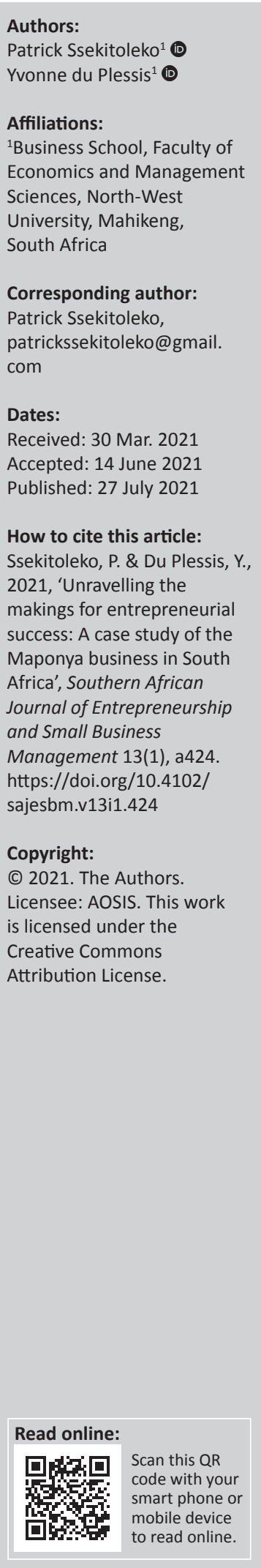

Background: The achievement of local entrepreneurial success in South Africa is projected to reduce widespread unemployment in the townships, enhance the general buying power and upraise the overall productivity and living standards of poor South Africans. However, most entrepreneurial ventures do not survive for long, and remarkably the number of selfestablished, privately owned and long-standing businesses amongst black South Africans is very few.

Aim: To investigate the factors that have led to the success and longevity of the Maponya business case.

Setting: This research focused on a privately owned, self-initiated black South African successful business, which has been in existence for at least six decades.

Methods: A qualitative research approach of a descriptive and explanatory single case study design was utilised using data from a semi-structured interview guide. Thematic and content analysis were used in the data analysis process.

Results and findings: It was found that the Maponya business case is a family-controlled type of business. The success and longevity of the Maponya business case are attributable to the closeness of members within the Maponya family or clan. Access to membership is well controlled and requires adherence to a set of values based on one another to prosper in business.

Conclusion: The documented findings can serve as a template for understanding the operationalisation of management techniques and leadership principles for entrepreneurial success and longevity in business for black South Africans and illuminate business prowess for the Southern African region and the entire African continent.

Keywords: black entrepreneurial success; entrepreneurship; family entrenchment; family business; Maponya business; South Africa.

\section{Introduction}

The sustained success of black-owned businesses, especially in South Africa, has been eagerly anticipated because of the unique history of the country. It is presumed that the prosperity of local businesses in the country is expected to benefit the community areas in which they operate by offering improved goods and services, adding to employment and contributing to uplift the overall standards of living systemically. Privately owned businesses play a significant role in adding to the national Gross Domestic Product (GDP) and increasing the tax base and revenue as well as the levels of employment, which in turn boost the economic growth of a country.

According to the Banking Association South Africa (TBASA 2019), South Africa's private sector comprises $91 \%$ of formal businesses, contributes about $34 \%$ to the country's GDP and about $60 \%$ employment of the total labour force. The Companies and Intellectual Property Commissions' (CIPC 2019) report from the Department of Trade and Industry (DTI) discloses that 378435 private companies were registered in the 2016-2017 financial year. For the year 2017-2018, 386373 companies were registered whereas 395320 private companies in the 2018-2019 financial year. Despite this reported constant year-on-year increment in the growth of the number of privately owned businesses, the recent annual Global Entrepreneurship Monitor (GEM 2017, 2018, 2019) reports on South Africa paint a disturbing picture particularly on sustained business ownership. Using the established business ownership rate (a percentage of adult population of between 18 and 64 years owning and managing a business that has paid salaries and other expenses to the owner for more than three and half years), the GEM reports estimate South Africa's established business ownership rate in 2017 at $2.5 \%, 2.2 \%$ for 2018 and 3.5\% for 2019. Such dismal figures 
could be construed as over $90 \%$ of adult South Africans are engaged in short-term business activities that cannot sustainably contribute to both the country's employment and GDP.

Still, in the South African context, the findings from the GEM reports are inconclusive on the categories such businesses belong to and the percentage share of black ownership. Annual data released by the Commission on Black economic empowerment (B-BBEEC 2020) reports that average company ownership by black people throughout the economy was just $27.83 \%$ in 2017, 25.2\% in 2018 and 29.4\% in 2019. Delving further into the same report reveals that black representation on the Johannesburg Stock Exchange-listed company boards stood at only 38\% in both 2017 and 2018, whilst for 2019, it was at $43.63 \%$. Such revelations reflect the discordance with the recent population estimates from STATS SA (2020) that depict South Africa's population to be $80.8 \%$ black, $8.8 \%$ coloured, $7.8 \%$ white and $2.6 \%$ Indian and/or Asian. This study should add to the debate and efforts in the promotion of equality in South Africa amongst all citizens towards level pegged sharing of control, ownership and wealth in the economy. This is because the increased presence of private enterprises amongst people is deemed pivotal to overall poverty level weakening (Hewitt \& Janse Van Rensburg 2020), justice and participation, wealth and observance of laws in the country (Nieman \& Pretorius 2004) as well as diminishing the inequalities between the rich and the poor in South Africa (Mogashoa \& Selebi 2021).

The DTI (2014) promotes the establishment of small- and medium-sized enterprises (SMEs) by mainly black South Africans to increase business ownership. This is because selfestablished, privately owned businesses by black South Africans seem to be scarce and in the hands of a few. It is possible that many of these businesses were nudged into inception with the help of the Black Economic Empowerment (BEE) programme after the abolition of apartheid in 1994. The questions that arise are why self-established, privately owned businesses amongst black South Africans are so few and how the few businesses that survived apartheid could grow despite difficult times to become successful and sustained to the present day.

\section{Research problem and question}

There is a view that most black-owned businesses in South Africa lack the necessary strength to last and be competitive locally and internationally, for instance, in terms of overall turnover, the total number of employees, stock exchange presence and continuation of this presence. In their account of the prosperity projections of South African new business ventures, Preisendorfer, Bitz and Bezuidenhout (2012:5) argue that many of the businesses owned by black people in the country are 'informal survivalists'. In other words, these are merely petite-sized and erratically managed businesses only meant to provide for the needs of owner individuals and their relatives. As many of South Africa's black population dwell dominantly in townships (McFarlane \&
Silver 2017; Preisendorfer, Boitz \& Bezuidenhout 2014), they are largely engaged in informal entrepreneurship (Beresford 2020; Maliehe 2017; Spiegel 2018). This may be construed that the operating environment and informal nature of most businesses run by black people in South Africa complicate their prosperity and sustainability outlook. This is defended by Beresford (2020) stating that in many instances township enterprises in South Africa continue to be informal and or in survival mode. South Africa's black entrepreneurial situation is compounded by the findings of Yeboah and Koffie (2016) who put the country's failure rate of newly started businesses to be the highest in the world at $75 \%$. This high level of failure is supported by Nheta et al. (2020) who indicate that only one in four businesses survive within 3 years of their formation in South Africa. Against this background of mainly entrepreneurship failure, very few success stories have been told, which this study aims to surface.

This study, therefore, sets off with the recognition of the scantiness of self-established, privately owned businesses amongst black South Africans who have survived the oppression of apartheid and succeeded despite difficult circumstances. Thomas (2020) maintains that the number of large, successful black-owned businesses in South Africa is few and those that have been in existence for over six decades are limited. In exploring the problem, as to why and how only some succeed, the success factors (enablers) of an iconic black-owned business are put forward as a business case. This is the South African Maponya business case, a blackinitiated and family-owned business that has been in existence for over six decades. The research question this study seeks to answers is: 'Why and how the Maponya family as entrepreneurs have been able to succeed at all odds to survive, sustain and grow a distinguished business empire' listed on the Johannesburg Stock Exchange?

\section{Research design and methods}

A qualitative research approach following a single case study design was employed as encouraged by Dul and Hak (2012) as this study aims to explore and distinguish a certain reality, giving insight into an intricate experience (Yin 2014), the unique success and longevity of the Maponya business case were chosen. A descriptive and explanatory case study strategy was utilised as espoused by Eriksson and Kovalainen (2008). Yin (2014:4) also supports the use of a case study design when 'the questions require an extensive and indepth description of some social phenomenon'.

\section{Case selection and data collection}

The researchers identified the Maponya Business case as a non-probability and purposively selected single case study, as endorsed by Dul and Hak (2012). Voluntary participation was sought, and permission was granted by the company executive to conduct the study and allow a selected member to participate in the study. Company documents were available as secondary data and primary data were collected from the company representative who participated as 
respondent is a Maponya family member. He had the means and experience to provide real evidence about the inner workings of the Maponya business case, thereby functioning as a case within the bigger business case (Yin 2014).

A semi-structured interview guide was developed and employed by the researcher for a deeper understanding and insight when conducting the interview (Creswell 2014). A lengthy time period was taken to collect data using direct and personal contact with the participant. Creswell (2014) and Fontana et al. (2005) promote the use of more time to deviate from the interview guide's prior arrangement of questions, which enables further probing during data collection. The result is richer and much more meaningful data. However, this was only after carrying out a pilot interview to test the interview guide as data collection instrument for validity (Ilker, Sulaiman \& Rukayya 2015; Van Teijlingen \& Hundley 2002) and to check for expected meaningful replies to questions in the interview guide (Rubin \& Babbie 2010).

The interview process was conducted in a setting where the respondent had the opportunity to engage fully (Yin 2014) and discuss the Maponya business history and manner of doing business. The interview, conducted in the English language, was audio-recorded after the participant's full consent. Company document reviews were carried out that provided more background against which the interview could be guided as supported by Creswell (2014), Eriksson and Kovalainen (2008) and Yin (2014).

\section{Data analysis}

The interview was transcribed verbatim, followed by close reading to get accustomed to the data and in aiding a clear understanding of the study context, as well as to observe gaps in the data where follow-up interviewing is necessary for clarity and completeness (Henning, Van Rensburg \& Smit 2004). Thereafter, the interview transcripts were coded following the steps of content analysis (Creswell 2014; Krippendorff 2013), using open coding, axial coding and selective coding (Maree 2007). Open-coded texts were clearly indicated on the transcript by hand to condense the interview data (Kaplan \& Maxwell 2005).

This was followed by compiling a code list (Creswell 2014; Gibbs 2010) on a separate page, capturing all the codes and grouping them into axial codes by searching for relationships, comparisons, differences and repetitions (Ryan \& Bernard 2003). The axial codes on the list were finally pared down to a manageable number (Gibbs 2010; Henning et al. 2004) for more insightful interpretation. A classification tree of the emerging themes based on selective coding was drawn up to show the relationships amongst the main themes and the subthemes in the data set, after reassessing themes and subthemes for inclusion (Braun \& Clarke 2006). Field notes jotted down (Babbie 2005) on critical subjects that arose throughout the interview process were valuable as vital reminders to stress important revelations from the key participant.
As the study used only one respondent, to ensure the reliability of data (Creswell 2014; Shenton 2004), the identified themes were triangulated with themes in the existing literature and also with member checking (Castro et al. 2011) to confirm the findings about the inner workings attributed to the success and longevity of the Maponya business case (i.e. researchers obtained verification from one senior member of the Maponya clan, who read the transcripts and data findings, that the identified themes and its descriptions were true representations of the Maponya business case).

\section{Results, findings and discussion}

From the data analysis, it was clear that the Maponya business success was based on continued family entrenchment. It must be emphasised that the researchers only discovered during the interview process that the Maponya business started and continued as a family-controlled type of business. Chua, Chrisman and Sharma (1999) classify a family business as one managed with the purpose to create and follow a dream that is endorsed by a principal union of family members or part of a family, a dream that is likely to be continued through the generations of the family or families. Though Longenecker et al. (2006) agree on the existence of a divide between the dynamics of family and business systems, with each having its own participants, aims and guiding principles, they concur that the constructs of family and business end up overlapping in a family type of business. Important to note also is that the words 'clan' and 'family' are used interchangeably in this study to refer to the family-ingrained nature of the Maponya business case, which could be equated to the 'familiness approach' referred to by Danes, Stafford and Amarapurkar (2009) where behavioural and social phenomena guide the business.

Therefore, to make sense of this overarching finding of familiness, the six main themes that make up a unique and consistent behavioural pattern of the Maponya clan members and contributing to the success and longevity of this family business will be elaborated on. The six themes are family solidity, family members' support of one another, work-forself nurturing, intense drive to succeed, strict disciplinary mechanisms and brand name significance.

\section{Family solidity}

It was found that the Maponyas are a closely interlaced clan of individuals who have, through the various lineages, always been in constant contact with one another. Keeping in touch with the goings-on of each member is a key differentiator of this family. The clan is bound together by means of an organisation called the Maponya Unity Movement, as explained by the respondent:

'The purpose of [such things] is to keep the link, closeness and power to influence within the Maponyas. This organisation has a president, a vice-president, treasury general, youth league, women's league, deputy treasury ... [all in the family].' (a Maponya family member, male, entrepreneur and lawyer, date unknown). 
This family closeness is evidenced by an event, called $a$ re tsebaneng (a Sepedi phrase for a form of mutual unselfishness according to which a person's happiness and the happiness of others are determined through a person's helpfulness), the annual compulsory clan gathering where Maponya families over generations get to know each other and also deal with issues amongst them. Keyt (2015) contends that this could be extant in a family business. Family closeness in a business set-up is also confirmed by Corbetta and Salvato (2004) as a pertinent detail resource favouring constructive family business performance. Likewise, family members closely identify with the business and remain loyal to it, albeit with no reward anticipated. Similarly, Keyt (2015) agrees that the same concept of unselfishness underpins family interconnectedness that persuades members to put business goals above their own.

\section{Family members' support of one another}

The Maponya clan members render assistance to each other in more ways than one. The respondent explained this support as follows:

'The question is that you can't divorce yourself from the family because the stakes are high, it is a support base, it defines who you are; the network defines who you are.' (a Maponya family member, male, entrepreneur and lawyer, date unknown).

This closeness in a family business denotes a survival strategy (Brewton et al. 2010), whereas Jang and Danes (2013) opine that this is a form of a cushion trait when family members intermingle closely to ensure, amongst other things, the existence of a family business particularly in challenging periods. It connotes a dependence logic and sincerity, which galvanises the wholeness of both dimensions of family and business (Danes \& Lee 2004). This family approach gives a great competitive edge to their business, for by virtue belonging to this particular clan, the members of this family business share in the benefits as expounded on below. This support of one another is further divided into the following:

\section{Sharing of business knowledge and experiences}

The clan cohesion amongst the Maponyas ensures that family members have each other's backs through sharing their business knowledge. Family members often work together in various sectors (even though members at times operate dissimilar businesses). The respondent had the following to say about the family's teamwork:

'My father was in the taxi business but because my uncles were in the meat business; they worked with him and helped him establish his own meat business. Richard Maponya, who owned the first black most successful butchery, trained and helped my dad to be able to establish his own meat business ... there was sharing of information and experiences from back then that ordinary people would not share if they operated independently.' (a Maponya family member, male, entrepreneur and lawyer, date unknown)

Business knowledge in a family firm is categorised by Chirico (2008) in terms of the good judgement and proficiency of members that is achieved through nurturing, tutoring and sharing experiences both internal and external to the business. This transmission of business knowledge within the family signifies an advantage for the family business, hence ensuring enormous achievement in business. Chirico (2008) and Trevinyo-Rodríguez and Tápies (2010) partly blame the collapse of family-owned companies to the reluctance to pass on information from one generation to another or even an unawareness of family members of the need to share. Information ought to reach all within a family business so that they can try out and introduce ways to tap into the know-how acquired by others in the family (Barroso, Sanguino \& Banegil 2013).

However, information-sharing is found by Stanely, Stephenson and Monteith (1995) to be hindered by envy amongst family members, which usually occurs when one member wishes to reach another's success level or one member or a small number of members may withhold important knowledge, which amplifies the centralisation of authority and stifles entrepreneurial actions and success within the family business (Zahra, Neubaum \& Larranetta 2007). Nonetheless, knowledge-sharing in family firms is made easier because of the existence of an across-the-board 'language' that enables the resourceful exchange of information (Hoffman, Hoelscher \& Sorenson 2006) fostered by dependence, loyalty and identity (Cabrera-Suàrez, SaáPérez \& García-Almeida 2001; Zahra et al. 2007). This unselfishness in sharing of industry information and experiences has been a vital component in ensuring the expansion and success of the Maponya business empire.

\section{Vast family network of business connections}

Given that many members of the Maponya clan are involved in various business fields, this hugely benefits many of them in bringing business to each other. This is facilitated by the above-mentioned sharing and close connection amongst all family members, enabling easier penetration of the market, branching out into scores of different business ventures and achieving market success. The following remark of the respondent can be noted here:

'The earlier members of the clan came up with this concept to use the clan power when they realised that as they grow, and they have children, and children have their grandchildren, there's a big network and the kids had to know each other.' (a Maponya family member, male, entrepreneur and lawyer, date unknown).

The shared ideals, dependence and customs amongst the families in a business give them social capital, which they utilise to deal or interact with other family members, thereby resolving issues amongst members, all of which adds to the competitive advantage of their businesses (Lester \& Cannella 2006).

Importantly, members are obligated to share their contacts and connections with the clan, and this further broadens the network of business connections. This is emphasised by the respondent: 
'We believe that my contacts do not belong to me, they belong to the clan; it is the clan that owns everything. Whatever I own, $[I]$ am duty-bound to share it with other members of the clan. One of my nephews owning the Mugg \& Bean downstairs [at the Mega City shopping complex] came to me and asked for my help. He wanted to be a businessman, he's a lecturer. But I couldn't turn him away, I had to share everything with him. I had to, you are compelled to.' (a Maponya family member, male, entrepreneur and lawyer, date unknown).

\section{Pool of resources and internal opportunities}

As could be gathered from the respondent's observation, the intermingling of the dimensions of both family and business and the support that members give one another create an abundance of resources that help buoy the business prospects of all in the Maponya clan. When referring to this, the respondent asserted:

'The way our family network works is similar to that of other ethnic or family types of business ... helping out each other in business. If there's a Maponya who does not have capital to bankroll a business venture, which you think is viable, you go to the president of the unity movement ... but if you don't have a close network with someone and we know someone is successful in that particular area, the president will ask that person to help you or a Maponya will accompany you to the bankers and be the guarantor to your loan, so you won't fail. Also, from the "a re tsebaneng" gatherings, some Maponyas who did not have jobs will meet successful entrepreneurs who will take them up.' (a Maponya family member, male, entrepreneur and lawyer, date unknown)

Through the sphere of family influence, there is an assortment of resources that contributes to entrepreneurial achievement in family businesses (Powell \& Eddleston 2013) and also to increased levels of business performance, continued existence and accomplishment (Aldrich \& Cliff 2003). Family business research has identified a number of resources that a family can offer a business, and these incorporate social, human and financial capital (Danes et al. 2009). It is the cross-dynamic nature of family firms and the indissolubleness of resources and ties amongst family members that give a family business a competitive edge (Habbershon, Williams \& MacMillan 2003). Such resources are used in either a domain or a system in response to a need in an opposite system (Muske \& Fitzgerald 2006), and entrepreneurs can without any trouble move these resources amongst the different domains (Aldrich \& Cliff 2003).

\section{Bursary fund}

Also clan members enjoy entitlement to The Richard Maponya Education Fund, named after the Maponya Movement's president, established to ensure the higher education of current and future generations to give them educational opportunities that earlier clan generations might not have had. Through this fund, members are assisted in acquiring skills in any field to improve their chances and to perform better. The respondent referred to this fund as follows:
'The bursary fund has a lot of money and was created to encourage all the Maponyas to attain a minimum matric level. If you do not have it, then we see [it] as if we are failing ourselves. But some people do not want to do academic work, but we think it is an important skill for you to get an education ... So there are funds that we donate every month, every year, that goes into the kitty.' (a Maponya family member, male, entrepreneur and lawyer, date unknown).

It may be construed that this readily available funding to further the skills of any Maponya family members helps them to venture into an assortment of businesses thereby expanding the Maponya businesses' footprint, apart from obviously reinforcing loyalty to the clan for the continued support of another.

\section{Work-for-self nurturing}

In their junior stages, the attitudes and practices of business management and entrepreneurship are inculcated by the elder Maponya generations, rather than encouraging them to seek employment. This approach differs from the most common path many ordinary families take, which is for adults to encourage their children to get employment and aim for career achievement. And this again speaks to a culture of mentorship within this family in which children gain invaluable hands-on business management experience early on, thus enabling the expansion, transformation of their parents' business entities later on. The respondent admitted:

'As a kid when I was raised, our parents never said we needed to
go to school in order to get the best job. My dad always said that
he was raising a family of kids that were going to contribute
towards the fiscus [purse] of the country and people who are
going to create jobs. I knew how to talk to the customer by the
age of nine. I was behind the counter, I was working in the shop,
I never played with other kids. I worked in a supermarket, I
knew how to greet a customer, I knew how to pack bread, I knew
how to treat a customer, I knew that you had to humble yourself.'
(a Maponya family member, male, entrepreneur and lawyer,
date unknown).

Allen et al. (2009) consider mentorship as a valuable human resource management component that is viewed to advance the vocation of the mentored person and is also advantageous to the firm. Additionally, Ragins and Verbos (2007) aver that business management mentors are able to capacitate their protégés and allow them to imbibe pertinent behaviours that facilitate proper business management.

\section{Intense drive to succeed}

There is immense pressure on the members of the Maponya families not to fail in the businesses they get into. Still, overcoming the heavy burden of expectation on one to succeed in a business venture is made easier owing to the already existing pool of contacts, connections and skillsupgrading opportunities that all the members have access to. All the same, as the respondent pointed out, members experience a lot of pressure: 
'The best motivating factor, in my view, is none other than someone you live in the same house with, or, put it differently, the stress levels within the Maponya clan are very high ... in terms of success are so high. So if you are a Maponya and you are an underperformer, you automatically become an outcast. I am not saying it is necessarily the right thing, but all the Maponyas are driven to succeed.' (a Maponya family member, male, entrepreneur and lawyer, date unknown).

Such intense drive to succeed resonates with the entrepreneurial inclination, a major trait of the Maponya families and is described by Hnátek (2015) to constitute a number of qualities ranging from being innovative, inventive, self-motivated, adaptable and opportunity-driven to possess the drive to create value whilst taking family and work colleagues into consideration.

\section{Strict disciplinary mechanisms}

Instrumental in maintaining the family-embedded nature for success and longevity of this business is the active penalising machinery that ensures adherence to the clan's respected ways of life. This, therefore, explains the family's unique behavioural trends and the near unrivalled calibre of its business achievement, which is shown below:

\begin{abstract}
'If someone says a negative thing about me here, my president or somebody hears about it, it gets reported and I get to be asked why, reminded that it doesn't build our name, we think it is wrong ... Then I may have to write a report to explain and account ... You have to toe the line, I am saying it, like, there are "police people" within that structure that report. For example, I haven't seen the president of our movement in, like, a month, but people will tell him, Mr Maponya is doing well, we like what he's doing ... and equally, if something was wrong, he will call to confirm and ask if the complaints are true.' (a Maponya family member, male, entrepreneur and lawyer, date unknown, [author's own emphasis])
\end{abstract}

Research on the control structures used in family businesses indicates the commonness of an influential eldest male or female who sets the tone of conduct (Zellweger \& Kammerlander 2015). This powerful leader in the family business directs all matters related to communication, administration, incentives and chastisement (Chandler 2015). Again, Le Breton-Miller and Miller (2015) acknowledge the importance of family councils as an authority apparatus to create rules of behaviour for family, business and social matters.

In incidences where the Maponya members do not conform to acceptable family behaviour, the following measures are turned to deter, to punish and rehabilitate members, thereby ensuring uniformity to the set rules of behaviour.

\section{Withdrawal of clan assistance and entitlements}

Clan members risk losing such privileges, and this compels them to go along with the expected code of conduct for the Mopanyas. This is attested to by the respondent:

'If you do not cooperate, you don't work with us, if you do not help others within the clan, then you will never get the help from the clan. Meaning, you are a Maponya and another kid requested help from you and it is within your field of specialisation or business or profession, and you refuse, and you get reported, and you're called but you still remain stubborn and don't help, then you automatically lose the benefits of being a clan member. You will not get the benefits and help that come to the clan members. And you might actually find yourself taking your kids out of the clan and from all the benefits because of your behaviours. So you're compelled to help any clan member that asks for help from you'. (a Maponya family member, male, entrepreneur and lawyer, date unknown).

Therefore culprits literally risk forfeiting their individual family's inheritance and all entitlements and birth-rights of being a Maponya and will suffer the consequences for the rest of their lives.

\section{Desertion}

Apart from scrapping non-conformists off the list of members designated to receive benefits and assistance, such members may also be banished from the clan. The respondent described the clan's approach as follows:

'Anything that puts the Maponya name out there in a bad light, the clan does not support it. Or anything considered wrong may not necessarily be illegal, but ethically wrong - boycott is applied ... Even if you are a rogue character, you can't be an open rogue in that family. It is ensured because we have got a structure.' (a Maponya family member, male, entrepreneur and lawyer, date unknown, [author's own emphasis])

Accordingly, the disciplinary structures within the Maponya clan ensure adherence to the set codes and principles so that members play it by the book, thus enabling the inner workings of the family components to stay glued together and facilitate the transfer of the practices and behaviours that make this family business to succeed and stay this long in operation.

\section{Brand name significance}

The Maponya clan associates themselves with the elephant (called tlou in the Sepedi language) and uses it as a symbol of identity and consolidation. An elephant, as the emblem, is used by all the companies owned by the clan members, as evidenced in one of the businesses' subdivisions website below in Figure 1.

An elephant is regarded as the ultimate symbol of success and portrayed as revered insignia by the Maponya clan members, through which identification and closeness are fostered. It is stated as such:

'So if you want anything from me, or any Maponya, and you call him by name or surname, it is nothing, but if you really want to twist their arms, you just say "tlou", which is an elephant.' (a Maponya family member, male, entrepreneur and lawyer, date unknown).

As all the members of the clan act in accordance with the family's honoured values, they are a mirror of their brand and they strengthen the image the public and their customers 


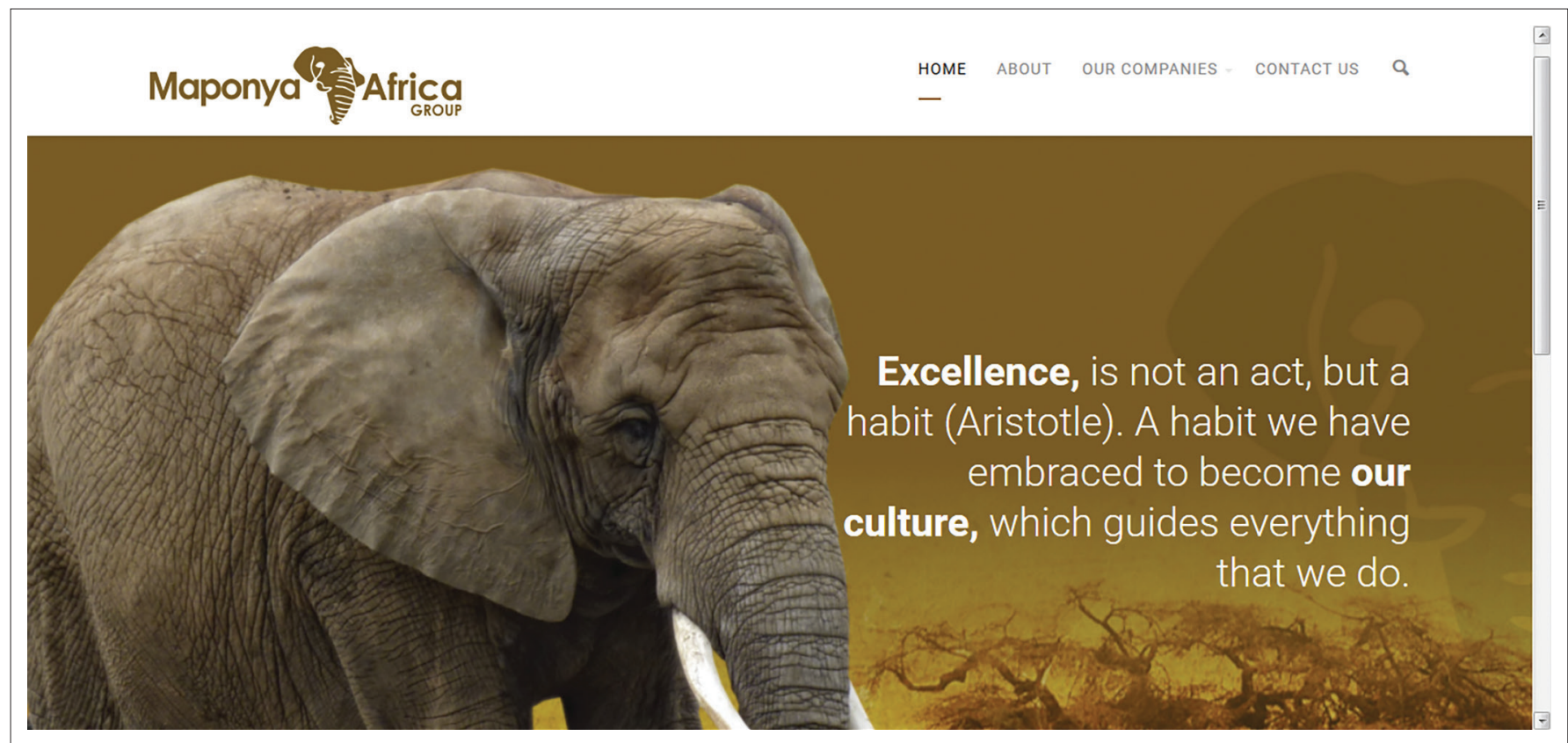

Source: Maponya Africa Group, n.d., Maponya Africa Group: Home, viewed 31 October 2019, from http://www.maponyaafrica.co.za/

FIGURE 1: A website of a Maponya company.

have of their business. This explains why there is a strict code of behaviour that all members have to follow, as revealed here:

'We were told and consistently reminded that as a Maponya, and I tell my kids too, we do not want to read any funny stories about the Maponyas in the newspapers ... we should just do the right thing ... Whatever we do, touch, we know the stress levels. And it is because it adds to the brand, it enhances the brand.' (a Maponya family member, male, entrepreneur and lawyer, date unknown [author's own emphasis]).

This is countersigned by Dyer and Whetten (2006) that in relation to corporate imaging, family businesses should endeavour to steer clear of social troubles and business mistakes. In other words, a family owning a business with its name on it is inclined to guard the family's reputation. More research from Craig, Dibrell and Davis (2008) and Sundaramurthy and Kreiner (2008) establishes that familyembedded brand uniqueness is associated with company performance and that these two factors have a role to play in attracting customers and increasing sales. The inseparability of family and business in a family type of business serves as a critical foundation for a unique advantage in personifying the family firm. Sundaramurthy and Kreiner (2008) argue that this renders duplication of such an entity almost unworkable. Therefore, through the sharing of the family's heritage, the shared image of the business and the clan members is enhanced. The corollaries from the Maponya brand name are.

\section{External opportunities}

People who hail from the Maponya clan, carrying the family name, have an edge already to prosper in business. Owing to the involvement of past generations of the family in business, members have benefitted from important business connections built up over time, which still is viewed as an accrual with the family brand name:

'If I go to the bank today, and I say I want to build a shopping centre ... a hotel, usually the tendency is that the Maponyas are known to have what it takes. They know how to drive business. Because you are from this clan, your father, your grandfather, everybody from this line being perceived to be from a family of winners. So there is willingness from partners, bankers ... as they have worked with the entrepreneurs of the Maponyas and all their businesses are very successful. So you get to jump that first hurdle as a Maponya, that most people are not gonna make it.' (a Maponya family member, male, entrepreneur and lawyer, date unknown).

\section{Reputation management}

This issue of protecting the Maponya brand was observed in most of the themes that emerged from the interview. The Maponyas have strong values and are value driven. Loyalty to the clan is not negotiable, and disloyalty is viewed as desertion (as seen above). Gotsi and Wilson (2001) discuss the importance of 'living' the brand if one wants to ensure a good reputation, and this is what is evidenced and is still continuing in the case of this black South African business. The study, nevertheless, points out that the high expectations of the clan, especially with members being forced to strictly adhere to the entrenched clan values, are repressive and pose challenges to all in the clan in some way or another.

\section{Discussion of key findings}

This study uncovered the factors responsible for the entrepreneurial success and longevity of the Maponya business case, as a black South African initiated and owned entity. It was found that the Maponya group of businesses is under a family-controlled organisation. This research has particularised the extent of the family embeddedness, which 


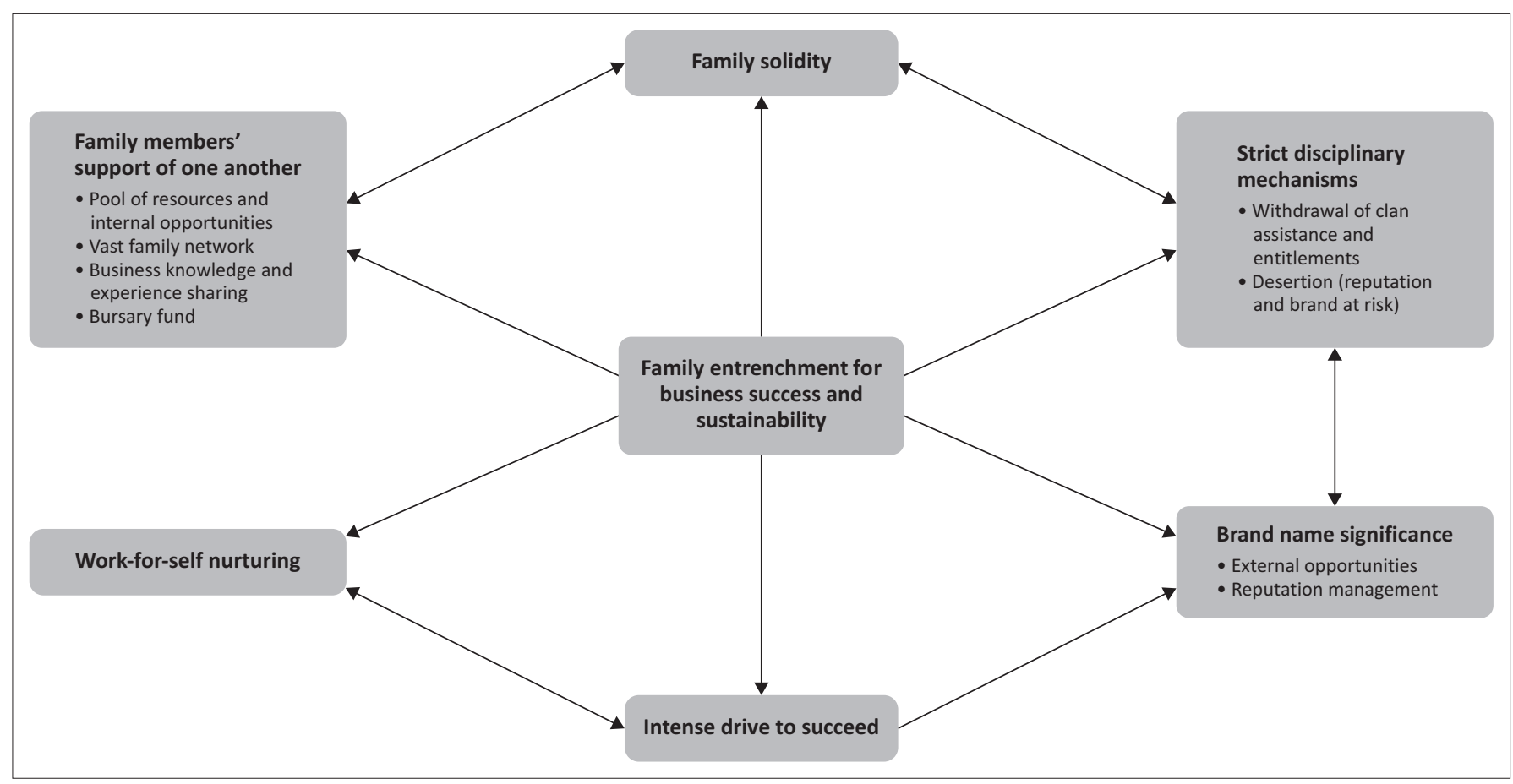

FIGURE 2: An illustration of the entanglement of family within the Maponya business case.

is the cardinal factor responsible for the success of the Maponya Business Empire or dynasty. Therefore, such a profound finding directed the review of the literature towards family business management to aid in corroborating most of the research findings, as shown above.

Based on the key findings, the study constructs Figure 2 to illustrate the deep-rooted nature of family as justification for the success and longevity of the Maponya business.

The pervasiveness of the Maponya family in business is directly and indirectly ascribed to its success, as members benefit from the family brand name to further their entrepreneurial endeavours. By using the family name (Maponya) as their business ventures' names, the Maponyas easily secure the buy-in of various stakeholders to enhance their business pursuits into prosperity. Important to note is that this brand name advantage has been built up over many years owing to the enforcement of strict adherence to family values (the Maponya way) by a disciplinary apparatus that keeps all clan members in line. The willingness of the family members to support one another in the form of readilyavailable mentoring of young family members, sharing of business knowledge and experiences and contributions to the education fund for members' skills development are key amongst the jealously guarded values of the Maponyas. This unique interdependence amongst clan members as an ageold family system has nurtured cohesion, harmony and general oneness. This has allowed the members to create and strengthen a huge network of business connections and vital resource pools (both internal and external to the family) to further the success of the Maponya businesses. There is also an entrepreneurial mindset and intense drive to succeed, traits instilled in young Maponyas during mentorship, to work for themselves and not seek jobs outside the clan. Such early-implanted business mindedness and skills have transformed the calibre of the Maponya business operations from mere merchandising in the early days, to much more sophisticated and modernised ventures.

In retrospect, these research findings showing the inner workings of the Maponya business empire tie in closely with the communal value systems characteristic of African cultural practices and are allegorical particularly to the practice of ubuntu. Mangaliso (2001) describes ubuntu as the enveloping will of love, neighbourliness and receptiveness within and amongst African people; it is based on their shared beliefs about the way they conduct themselves and treat those they come across. Central to ubuntu are the concepts of the mutual dependence of people, preference for collectivism over individualism and exercising restraint from self-regarding.

\section{Study limitations and strengths}

There could be uneasiness about the ability to draw conclusions from results of a single case study, as the information was obtained from only one clan member of the Maponyas. However, the findings were approved by a senior Maponya family member (member checking) to allay validity concerns. Creswell (2014) announces that sometimes it may be the case that research findings cannot be interpreted to represent the entire population. Yet again, Bricki and Green (2007) regard a small sample size to be adequate especially in qualitative research as it allows a deeper understanding of the case selected. The findings, albeit from a single business case, offer hope for black South Africans with an aim for entrepreneurial success. The inner workings of the Maponya business dynasty revealed in this study may be used as a 
template to conduct and excel in business, particularly in an African context.

\section{Future research}

Further research, using either qualitative or quantitative methods may be conducted to supplement existing knowledge about black African business leadership and success. In the current study, only one entrepreneur (a member of the Maponya family) was interviewed; therefore this study could be expanded to include interviews with more members of the Maponya family to bear witness to the findings from this one case within the Maponya case, thereby making possible the generalisation of the Maponya business model.

There is need to investigate succession planning and transitional processes used by older Maponya generations to facilitate the continued running of businesses by the younger generations. This is a crucial strategic management process that needs further probing to reveal how the right family members are chosen to lead and to account for the sustainability of this business empire.

Maponya's business reputation management could be probed on how their businesses expand to involve business partners and employees outside the Maponya clan. The study established that the Maponya business empire is a family-controlled type of business, with family members expected to stick to a particular behavioural pattern emblematic of their reputation and upbringing, key to doing business. It would thus be worthy research to learn how their brand is still upheld when in partnership with nonMaponyas, who are of different values and backgrounds.

Further research may include other businesses to possibly allow for more generalisable results. For instance, a comparative analysis between the Maponya business and other similar businesses might also be considered.

\section{Conclusion}

This case study brought to the fore the factors for the immense success and longevity of a previously disadvantaged group, the Maponya entrepreneurial business in South Africa. The results provide deeper insights into and understanding of the application of business management and leadership principles within a true African business context. The findings unpack the business case employed in the Maponya business. Accordingly, this research believes that the findings could give black African entrepreneurs, with aspirations to achieve business success, more insight into business management operations and methods by virtue of the example set by the Maponya family business. The findings explain a distinctiveness of a black African business dynasty, provide scholarly facts, broadening the knowledge base on African business management techniques and accomplishments in a Southern African and African context and, also, on the topic of family business studies in a general African sense.

\section{Acknowledgements}

A huge chunk of this work emanates from P. Ssekitoleko's mini-dissertation, entitled 'Sustainable entrepreneurial success: a case study of the Maponya business in South Africa', submitted in partial fulfilment for the degree, Masters of Business Administration in 2017.

\section{Competing interests}

The authors declare that they have no financial or personal relationships that may have inappropriately influenced them in writing this article.

\section{Authors' contributions}

Both authors planned the research, but P.S. conducted the research, reviewed the literature, formulated the research design, collected and analysed the data, made interpretations and finalised the report. Y.P. supervised the research project.

\section{Ethical considerations}

This article followed all ethical standards for research.

\section{Funding information}

The North-West University sponsored this research.

\section{Data availability}

The data that support the findings of this study are available upon reasonable request.

\section{Disclaimer}

The views and opinions expressed in this article are those of the authors and do not necessarily reflect the official policy or position of any affiliated agency of the authors.

\section{References}

Aldrich, H.E. \& Cliff, J.E., 2003, 'The pervasive effects of family on entrepreneurship: Toward a family embeddedness perspective', Journal of Business Venturing 18(5), 573-596. https://doi.org/10.1016/S0883-9026(03)00011-9

Allen, T.D., Smith, M.A., Mael, F.A., O’Shea, P.G. \& Eby, L.T., 2009, 'Organizational-level mentoring and organizational performance within substance abuse centres', Journal of Management 35(5), 1113-1128. https://doi.org/10.1177/0149206308329969

Babbie, E., 2005, The basics of social research, 3rd edn., Thomson Wadsworth, Belmont, CA.

Barroso, A.M., Sanguino, R.G. \& Banegil, T.P., 2013, 'Study of factors influencing knowledge transfer in family firm', Intangible Capital 9(4), 1216-1238. https://doi. org/10.3926/ic.405

Broad-Based Black Economic Empowerment Commission (B-BBEEC), 2020, National status and trends on broad-based black economic empowerment, 10 June 2020. V04.00, Department of Trade \& Industry (DTI), Pretoria.

Beresford, M., 2020, 'Entrepreneurship as legacy building: Reimagining the economy in post-apartheid South Africa', Economic Anthropology 7(1), 65-79. https://doi. org/10.1002/sea2.12170

Braun, V. \& Clarke, V., 2006, 'Using thematic analysis in psychology', Qualitative ResearchinPsychology3(2),77-101.https://doi.org/10.1191/1478088706qp063oa

Brewton, K.E., Danes, S.M., Stafford, K. \& Haynes, G.W., 2010, 'Determinants of rural and urban family firm resilience', Journal of Family Business Strategy 1(3), 155-166. https://doi.org/10.1016/j.jfbs.2010.08.003

Bricki, N. \& Green, J., 2007, A guide to using qualitative research methodology, viewed 01 March 2020, from https://fieldresearch.msf.org/handle/10144/84230.

Cabrera-Suàrez, K., Saá-Pérez, P. \& García-Almeida, D., 2001, 'The succession process from a resource- and knowledge-based view of the family firm', Family Business Review 14(1), 37-38. https://doi.org/10.1111/j.1741-6248.2001.00037.x 
Castro, V., Garcia, E.E., Cavazos, J., Jr. \& Castro, A.Y., 2011, 'The road to doctoral success and beyond', International Journal of Doctoral Studies 6, 51-77. https:// success and beyond,'
doi.org/10.28945/1428

Chandler, G.N., 2015, 'Control structures used in family business to manage wealth Operationalisation of antecedent and outcome variables', Entrepreneurship Theory and Practice 39(6), 1305-1312. https://doi.org/10.1111/etap.12175

Chirico, F., 2008, 'Knowledge accumulation in family firms: Evidence from four case studies', International Small Business Journal 26(4), 433-462. https://doi. org/10.1177/0266242608091173

Chua, J.H., Chrisman, J.J. \& Sharma, P., 1999, 'Defining the family business by behaviour', Entrepreneurship Theory and Practice 23(4), 19-39. https://doi. org/10.1177/104225879902300402

Companies and Intellectual Property Commission (CIPC), 2019, CIPC annual report 2018/2019, Department of Trade \& Industry (DTI), Pretoria.

Corbetta, G. \& Salvato, C., 2004, 'Self-serving or self-actualising? Models of man and agency costs in different types of family firms: A commentary on "comparing the agency costs of family and non-family firms: Conceptual issues and exploratory evidence"', Entrepreneurship Theory and Practice 28(4), 355-362. https://doi. org/10.1111/j.1540-6520.2004.00050.x

Craig, J.B., Dibrell, C. \& Davis, P.S., 2008, 'Leveraging family-based brand identity to enhance firm competitiveness and performance in family business Journal of Small Business Management 46(3), 351-371. https://doi. org/10.1111/j.1540-6520.2004.00050.x

Creswell, J.W., 2014, Research design: Qualitative, quantitative, and mixed methods approaches, 3rd edn., SAGE, Los Angeles, CA.

Danes, S.M. \& Lee, Y.G., 2004, 'Tensions generated by business issues in farm businessowning couples', Family Relations 53(4), 357-366. https://doi. org/10.1111/j.0197-6664.2004.00042.x

Danes, S.M., Stafford, K.H.G. \& Amarapurkar, S.S., 2009, 'Family capital of family firms: Bridging human, social and financial capital', Family Business Review 22(3), 199-216. https://doi.org/10.1177/0894486509333424

Department of Trade and Industry (DTI), 2014, Proclamation by the President of the Republic of South Africa.

Dul, J. \& Hak, T., 2012, Case study methodology in business research, Routledge, New York, NY.

Dyer, Jr., G. \& Whetten, D.A., 2006, 'Family firms and social responsibility: Preliminary evidence from the S\&P 500', Entrepreneurship Theory and Practice 30(6), 785-802.

Eriksson, P. \& Kovalainen, A., 2008, Qualitative methods in business research, Sage, London.

Fontana, A., Frey, J.H., Denzin, N.K. \& Lincoln, Y.S., 2005, The Sage handbook of qualitative research, Sage, Thousand Oaks, CA.

Gibbs, G.R., 2010, Coding Part 1: Alan Bryman's 4 stages of qualitative analysis (Web Video), viewed 24 January 2020, from http://www.youtube.com/watch?v=7X7V QxPfpk\&feature=list_other\&playnext=1\&list=SP14E49EDF20613008.

Global Entrepreneurship Monitor (GEM), 2017, Global report 2016/2017, Global Entrepreneurship Research Association (GERA), London.

Global Entrepreneurship Monitor (GEM), 2018, Global report 2017/2018, Global Entrepreneurship Research Association (GERA), London.

Global Entrepreneurship Monitor (GEM), 2019, Global report 2018/2019, Global Entrepreneurship Research Association (GERA), London.

Gotsi, M. \& Wilson, A., 2001, 'Corporate reputation management: "living the brand"' $\begin{array}{lll}\text { Management Decision 39(2), } & \text { 99-104. } & \text { https://doi.org/10.1108/ } \\ \text { EUM0000000005415 } & & \end{array}$

Habbershon, T.G., Williams, M.L. \& MacMillan, I.C., 2003, 'A unified systems perspective of family firm performance', Journal of Business Venturing 18(4), 451-465. https://doi.org/10.1016/S0883-9026(03)00053-3

Henning, E., Van Rensburg, W. \& Smit, B., 2004, Finding your way in qualitative research, Van Schaik, Pretoria.

Hewitt, L.M.M. \& Janse Can Rensburg, L.J., 2020, 'The role of business incubators in creating sustainable small and medium enterprises', Southern African Journal of Entrepreneurship and Small Business Management 12(1), a295. https://dol. org/10.4102/sajesbm.v12i1.295

Hnátek, M., 2015, 'Entrepreneurial thinking as a key factor of family business success', Procedia-Social and Behavioral Sciences 181, 342-348. https://doi.org/10.1016/j. sbspro.2015.04.896

Hoffman, J., Hoelscher, M. \& Sorenson, R., 2006, 'Achieving sustained competitive advantage: A family capital theory', Family Business Review 19(2), 135-145. advantage: A family capital theory', Family Busines
https://doi.org/10.1111/j.1741-6248.2006.00065.x

Ilker, E., Sulaiman, A.M. \& Rukayya, S.A., 2015, 'Comparison of convenience sampling and purposive sampling', American Journal of Theoretical and Applied Statistics 5(1), 1-4. https://doi.org/10.11648/j.ajtas.20160501.11

Jang, J. \& Danes, S.M., 2013, 'Role interference in family businesses', Entrepreneurship Research Journal' 3(3), 367-390. https://doi.org/10.1515/erj-2012-0020

Kaplan, B. \& Maxwell, J.A., 2005, 'Qualitative research methods for evaluating computer information systems', in J.G. Anderson \& C.E. Aydin (eds.), Evaluating
the organizational impact of healthcare information systems, pp. 30-55Springer, the organization

Keyt, A., 2015, The 4 forces that drive family business success, viewed 09 November 2019, from https://www.entrepreneur.com/article/250416.

Krippendorff, K., 2013, Content analysis: An introduction to its methodology, 3rd edn. Sage, Los Angeles, CA.

Le Breton-Miller, I. \& Miller, D., 2015, 'Learning stewardship in family firms: For family, by family, across the life cycle', Academy of Management Learning and Education 14(3), 386-399. https://doi.org/10.5465/amle.2014.0131
Lester, R.H. \& Cannella, A.A., Jr., 2006, 'Interorganisational familiness: How family firms use interlocking directorates to build community-level social capital', Entrepreneurship Theory and Practice 30(6), 756-775. https://doi. Entrepreneurship Theory and Pract
org/10.1111/j.1540-6520.2006.00149.x

Longenecker, J.G., Moore, C.W., Petty, J.W. \& Palich, L.E., 2006, Small business management: An entrepreneurial emphasis, Thomson South-Western, Mason, $\mathrm{OH}$.

Maliehe, S., 2017, 'The rise and fall of African indigenous entrepreneurs' economic solidarity in Lesotho, 1966-1975', African Economic History 45(1), 110-137. https://doi.org/10.1353/aeh.2017.0003

Mangaliso, M.P., 2001, 'Building competitive advantage from "ubuntu": Management lessons from South Africa', The Academy of Management Executive 15(3), 23-34. https://doi.org/10.5465/ame.2001.5229453

Maponya Africa Group, n.d., Maponya Africa Group: Home, viewed 31 October 2019, from http://www.maponyaafrica.co.za/.

Maree, K., 2007, First steps in research, Van Schaik, Pretoria.

McFarlane, C. \& Silver, J., 2017, 'The poolitical city: 'Seeing sanitation' and making the urban political in Cape Town', Antipode 49(1), 125-148. https://doi.org/10.1111/ anti.12264

Mogashoa, M.M. \& Selebi, O., 2021, 'Innovation capacity: A perspective on innovation capabilities of consulting engineering firms', Southern African Journal of Entrepreneurship and Small Business Management 13(1), a372. https://doi. org/10.4102/sajesbm.v13i1.372

Muske, G. \& Fitzgerald, M.A., 2006, 'A panel study of copreneurs in business: Who enters, continues and exits?', Family Business Review 19(3), 192-205. https://doi org/10.1111/j.1741-6248.2006.00070.x

Nheta, D.S., Shambare, R., Sigauke, C. \& Tshipala, N., 2020, 'Entrepreneurship gaps framework model: An early-stage business diagnostic tool', Southern African Journal of Entrepreneurship and Small Business Management 12(1), a297. https:// doi.org/10.4102/sajesbm.v12i1.297

Nieman, G. \& Pretorius, M., 2004, Managing growth: A guide for entrepreneurs, Juta, Cape Town.

Powell, G.N. \& Eddleston, K.A., 2013, 'Linking family-to-business enrichment and support to entrepreneurial success: Do female and male entrepreneurs experience different outcomes?', Journal of Business Venturing 28(2), 261-280. https://doi.org/10.1016/j.jbusvent.2012.02.007

Preisendorfer, P., Bitz, A. \& Bezuidenhout, F.J., 2012, 'Business start-ups and their prospects of success in South African townships', South African Review of Sociology 43(3), 3-23. https://doi.org/10.1080/21528586.2012.727542

Preisendorfer, P., Boitz, A. \& Bezuidenhout, F.J., 2014, 'Black entrepreneurship: A case study on entrepreneurial activities and ambitions in a South African township', Journal of Enterprising Communities: People and Places in the Global Economy 8(3), 162-179. https://doi.org/10.1108/JEC-02-2012-0020

Ragins, B.R. \& Verbos, A.K., 2007, 'Positive relationships in action: Relational mentoring and mentoring schemas in the workplace', in J. Dutton \& B.R. Ragins (eds.), Exploring positive relationships at work: Building a theoretical and research foundation, pp. 91-116, Lawrence Erlbaum, Mahwah, NJ.

Rubin, A. \& Babbie, E., 2010, Essential research methods for social work, Thomson Brookes/Cole, Belmont, CA.

Ryan, G.W. \& Bernard, H.R., 2003, 'Techniques to identify themes', Field Methods 15(1), 85-109. https://doi.org/10.1177/1525822X02239569

Shenton, A.K., 2004, 'Strategies for ensuring trustworthiness in qualitative research projects', Education for Informtion 22(2), 63-75. https://doi.org/10.3233/EFI2004-22201

Spiegel, A.D., 2018, 'Reconfiguring the culture of kinship: Poor people's tactics during South Africa's transition from apartheid', Africa 88(1), 90-116. https://doi. org/10.1017/S0001972017001164

Stanely, C., Stephenson, B. \& Monteith, D., 1995, 'The management of family firms: An empirical investigation', International'Small Business Journal 13(4), 11-34. https:// doi.org/10.1177/0266242695134001

Statistics South Africa (STATS SA), 2020, Mid-year population estimates. Statistical release P0302, Department of Statistics South Africa, Pretoria.

Sundaramurthy, C. \& Kreiner, G.E., 2008, 'Governing by managing identity boundaries: The case of family businesses', Entrepreneurship Theory and Practice 32(3), The case of family businesses', Entrepreneurship Theory and
415-436. https://doi.org/10.1111/j.1540-6520.2008.00234.x

The Banking Association South Africa (TBASA), 2019, Small \& medium enterprise, viewed 01 March 2021, from https://www.banking.org.za/what-we-do/sme/.

Thomas, D., 2020, Black economic power matters: Is South African transformation dead?, viewed 04 March 2021, from https://african.business/2020/09/economy/ black-economic-power-matters-is-south-african-transformation-dead/.

Trevinyo-Rodríguez, R.N. \& Tàpies, J., 2010, Effective knowledge transfer in family business, Working Paper 865, IESE Business School, University of Navarra, Barcelona.

Van Teijlingen, E. \& Hundley, V., 2002, 'The importance of pilot studies', Nursing Standard 16(40), 33-36. https://doi.org/10.7748/ns.16.40.33.s1

Yeboah, A.M. \& Koffie, F., 2016, 'Does the legal form of small and medium enterprises determine their access to capital', International Journal of Management, Accounting, and Economics 3, 520-533.

Yin, R.K., 2014, Case study research. Design and methods, 5th edn., SAGE, Los Angeles, CA.

Zahra, S., Neubaum, D. \& Larranetta, B., 2007, 'Knowledge sharing and technological capabilities: The moderation role of family involvement', Journal of Business Research 60(10), 1070-1079. https://doi.org/10.1016/j.jbusres.2006.12.014

Zellweger, T. \& Kammerlander, N., 2015, 'Family, wealth and governance: An agency account', Entrepreneurship Theory and Practice 39(6), 1281-1303. https://doi. org/10.1111/etap.12182 